\title{
TO BE OR NOT TO BE: AMERICAN INFLUENCE ON LGBT+ RIGHTS IN BULGARIA
}

\author{
Iskren IVANOV \\ Senior Lecturer of International Relations and U.S. Foreign Policy \\ Sofia University "St. Kliment Ohridski" \\ Visiting Lecturer of U.S./Russia Foreign Policy \\ The University of Texas at Austin \\ E-mail: i_ivanov@phls.uni-sofia.bg
}

\section{Alexander DRAGANOV}

Ph.D. Student, Comparative Politics

Sofia University "St. Kliment Ohridski"

E-mail: adraganov@phls.uni-sofia.bg

\begin{abstract}
The purpose of this article is to assess the U.S. influence on the public perceptions towards LGBT+ people in Bulgaria. The research design incorporates several variables collected through in-person observations and comparative analysis of case studies. In this paper, we try to explain the increasing American influence and the gender aspect of U.S. Foreign Policy in the Balkans. To offer a more detailed analysis, we have employed an approach that compares the liberal wave in the United States, which advocates LGBT+ rights, to the conservative movements that promote homophobia under the guise of Eastern European traditions. The article argues that the debate about LGBT+ rights in Bulgaria mirrors the striking political and ideological polarization, which divides contemporary American society. Our study asserts that the public debate in Bulgaria reflects the neo-conservative attitudes of Russia and Moscow's contradictory policy of sexual discrimination. Finally, we conclude that the United States also exercises significant cultural and political influence, not to say pressure, on the Bulgarian political elite to recognize the freedoms of LGBT+ people, which triggers a backlash and favors rightwing populist movements. We begin with a short critical review of the contemporary trends in the anti-LGBT+ rhetoric in Bulgaria. Then, we examine the most relevant official and unofficial American positions about sexual discrimination to assess the impact of the U.S. influence. Finally, we conclude with
\end{abstract}


a qualitative analysis of reliable sources from the Bulgarian media.

Keywords: gender, policy, Bulgaria, United States, rights

\section{Introduction}

The problems LGBT+ Bulgarians face have been polarizing the Bulgarian society since the collapse of Communism. These two views dominate the public debate in Bulgaria. The first and prevalent assumption is that homophobia is not a problem for Bulgarian people and that the LGBT+ community can thoroughly enjoy the Constitutional freedoms. Proponents of that view reject the freedom of sexual minorities to express their rights by stating that parading with the latter has a detrimental influence on the young generation. (McGarry, 2016, p. 274). The other faction, currently constituting a minority, claims that Bulgarian culture is hostile towards LGBT+ values and that if you are gender non-conforming or with a sexual orientation different from the "traditional" one, you should go straight. (Godzisz and Vigianni, 2019, p. 174) Activists give examples such as the murder of a student, who, according to his assailants, "looked gay," attacks on discussions of books and movies featuring LGBT+ protagonists, and everyday cruelties, including the assaults on LGBT+ young people. Domestic violence over children also provides a perfect example of widespread gender violence with striking implications on the victims' cognitive maturation. There seems to be a consensus that Bulgaria is not as unfavorable for LGBT+ people as Russia or other Eastern European countries like Poland or Hungary. Yet, it is a place many of them would choose to leave rather than suffer the outcast's life.

The purpose of this article is to assess the U.S. influence on the public perceptions towards LGBT+ among Bulgaria. Our research design incorporates several variables collected through in-person observations and comparative analysis of case studies. The dependent variable reflects the current trends in LGBT+ communities and their activities, and the independent involves the gender reflections of the U.S. Foreign Policy in the Balkans. For the purposes of this article, we have chosen to review existing publications from both academia and the media due to the high relevance of the problem. Last but not least, we have analyzed different points of view so that the article could serve as a plausible starting point for other writings on gender studies.

This paper also seeks to explain the increasing American influence and the gender aspect of U.S. Foreign Policy in the Balkans. To offer a more detailed analysis, we have employed an approach that compares the liberal wave in the United States, which advocates LGBT+ rights, to the conservative movements that promote homophobia under the guise of Eastern European traditions. The article argues that the debate about LGBT+ rights in Bulgaria mirrors the striking political and ideological polarization, which divides contemporary American society. Our second assumption is that the public debate in Bulgaria reflects the neo-conservative attitudes of Russia and Moscow's contradictory 
policy of sexual discrimination. Finally, we conclude that the United States also exercises significant cultural and political influence, not to say pressure, on the Bulgarian political elite to recognize the freedoms of LGBT+ people, which triggers a backlash and favors right-wing populist movements.

The research roadmap of this article follows a three-level approach. We begin with a short critical review of the contemporary trends in the anti-LGBT+ rhetoric in Bulgaria. Then, we examine the most relevant official and unofficial American positions about sexual discrimination to assess the impact of the U.S. influence. Finally, we conclude with a qualitative analysis of reliable sources from the Bulgarian media. Our approach is specific in two ways. First, this is not an article about asymmetrical or ideological warfare but an objective examination of the gender aspect of U.S. Foreign Policy in the Balkans. Second, our paper does not deal with conspiracies but instead seeks to explain how the American influence in Eastern Europe reshapes public perceptions in countries like Bulgaria.

\section{LGBT+ rights in Bulgaria: between post-socialism and liberalism}

Our first assertion is that despite the difficulties discussed above, there seems to be consistent progress on LGBT+ rights in Bulgaria. There are even more Bulgarian websites on the topic, including a couple of news portals like Huge.BG and Out.BG, virtual communities such as GenderLand. In addition, Bulgarians enjoy the support of selected mainstream media like Dnevnik or ClubZ. The annual Sofia Pride becomes more and more successful and attractive for gender communities with each passing year, while foundations such as Single Step offer support to LGBT+ underage. However, it is essential to highlight that there is also a growing discontent among nationalists and farright activists against public discussions of LGBT+ topics. This deviation from the public discourse was visible in the debates surrounding the Istanbul Convention. The vast majority of the Bulgarians considered the Convention a referendum about the rights of LGBT+ people, although its primary purpose was the protection of women from domestic violence.

A short overview of the debatable document could shed light on public attitudes in Bulgaria. The Council of Europe Convention on preventing and combating violence against women and domestic violence is a classical intergovernmental treaty opened for ratifying in Istanbul, hence its name. In January 2018, the Council of Ministers of the Bulgarian Republic offered a proposal to the Bulgarian Parliament to further ratify the Convention. The actions of the Council triggered widespread protests and faced mass disapproval as people tended to believe that ratification of the Convention would ensure a formal recognition of the third gender and same-sex marriages (Council of Europe, 2018). Although the Convention's proponents provided the citizens with thoughtful arguments and rational interpretation of the document, the Bulgarian society opposed it, using statements that were openly homophobic or transphobic (Bankov, 2020, p. 347). Major religious organizations such as the Bulgarian Orthodox Church, the Catholic Church in Bulgaria, and The Grand Mufti all condemned the convention, rebuking its claim that gender is a social 
construct, separate from the biological sex (Stoencheva, 2021, p. 37) (Darakchi, 2019, p. 1223). The only religious community, which supported the Convention, was the Organization of the Bulgarian Jews "Shalom." (Darakchi, 2019, p. 1222). In the aftermath, the Bulgarian government delegated the final decision to the Bulgarian Constitutional Court, which declared that the Istanbul Convention was not compatible with the Constitution of Bulgaria and, thus, could not be integrated with the Bulgarian law (Ilcheva, 2020, p. 49).

In a more recent development, the Constitutional Court passed a definition of sex, defining it as a biological category. Some experts argue that such a decision empowers Bulgarian citizens with the right to have only biological sex, not gender (Burke and Molitorisova, 2019, p. 190). The mass demonstrations of the right-wing movements, which approved the decision, evolved into organized hatred against LGBT+ people alongside public attacks and protests against gatherings of gender communities or even simple signs of public affection. (Strand and Svenson, 2021, p. 16) Although the analyzed Convention enjoyed solid support from the United States and European Union, its ratification failed. Moreover, the attempts of the Bulgarian government to pass the document and integrate it into the Bulgarian legal framework provoked a strong antiAmerican and anti-European sentiment among Bulgarians. To conclude, although the transition to democracy in Bulgaria finished with the accession to the North Atlantic Treaty Organization and European Union, it seems that the LGBT+ rights are not likely to become part of the Bulgarian legislature in the near future.

\section{U.S. Foreign Policy and the moral stick of American Evangelicals.}

This section will conduct a short assessment of the current trends in American support for LGBT+ Bulgarians. The U.S. Embassy in Bulgaria has expressed a strong commitment to LGBT+ people, with the U.S. support is not limited to Sofia Pride or other mass events (US Embassy, 2017), though it is a common practice for key officers from the Embassy to attend the Pride. In 2011, the Embassy even sponsored a gay film festival to promote the liberal understanding of gender studies. In 2020, the U.S. Department of State Report on Human Rights and Labor was highly critical that no Bulgarian laws provide LGBT+ Bulgarians with protection from hate crimes (Bureau of Democracy, Human Rights and Labor, 2020). Academic institutions have always been active and engaging in the LGBT+ cause. The American College in Sofia expresses support for its LGBT+ students regularly and even established Alliance clubs. A former teacher at the College, Garth Greenwell, wrote a book about his experiences as a gay man and a teacher in Bulgaria. The American University in Bulgaria also backs LGBT+ Bulgarians by opening a campus discussion about building tolerance.

However, our analysis of the gender aspects in the U.S. Foreign Policy also infers detrimental effects on gender communities. American Evangelicals are believed to have invested millions of dollars for "pro-family" campaigns in Europe, including Bulgaria (Darakchi, 2021). Organized attacks on the Pride and financial support for the "family unions" are plausible expressions of the 
Evangelical policy, which we define as a moral stick. Therefore, our second conclusion is that the public debate in Bulgaria reflects the ideological fights of the polarized and divided American society. Culture wars in the United States are the arguments of social issues, which often divide the Democrats and the Republicans. Like Bulgarian debates, cultural conflicts in America emerge from racial issues, women's rights, rights of religious minorities, anti-abortion campaigns (pro-life and pro-choice), and social justice (Thomson, 2010, p. 120). History offers no better example than the uprisings, which started in the turbulent 1960s when the hippy movement challenged the traditional habits and wisdom (Howard, 1969, p. 50). However, they later faced backlash from the "the silent majority" of Americans, who stood by the Conservatives and voted for their candidate Ronald Reagan (Spitzer, 2013, p. 40). In the Reagan era, life for LGBT+ Americans was far from perfect, as their ranks were decimated by the HIV Pandemic, which according to some, were underestimated by the thenRepublican administration. Back in 1994, U.S. President Bill Clinton introduced the "Don't Ask, Don't Tell" policy to the U.S. Military, a variation of the common trope that "gays are accepted till they start parading." (Burks 2011, p. 604) Although President Clinton considered this concept progressive at that time, it was pronounced discriminatory almost two decades later (Belkin, 2003 , p. 4). As attitudes towards LGBT+ people changed, conservative voices switched from denial of homosexuality per se to opposition against same-sex marriage, as they said they were defending the "traditional institution of marriage" (McVeigh, 2019, p. 900). Finally, the Supreme Court of the United States postulated the right of same-sex couples to live under civil union after resolving the Obergefell v Hodges case (Hermann, 2015, p. 367). However, cultural wars in the United States sparked as experts debated differences between sex and gender. The problematic issue is allowing biologically male people into women-only places such as sanctuaries for victims of domestic violence, bathrooms, and sports (Rowling, 2020). To sum up, the liberal position support of LGBT+ rights has often been articulated by members of the popular culture and, more recently, the tech elite of the Silicon Valley. In contrast, the conservative arguments against those rights are often seen in profamily groups related to evangelical Christianity. We can easily observe how these influences can be exported to a smaller country like Bulgaria.

\section{Defining the case studies: Bulgarian "genders."}

This section purports to apply the theoretical framework we employed for this article with the empirical data we collected through in-person observations. Before discussing the variable, it is essential to emphasize the methodological difficulties we faced during our research. First, most of the respondents reject conversations about LGBT+ rights in Bulgaria due to objective issues. Most of them consider themselves threatened or potentially deprived of their right to self-identity. We believe that this is the most complicated weakness of all gender researches in the Balkans. The second problem arises from the lack of other studies in that field. It is challenging to muster empirical data and to infer hypotheses only from a limited number of interviews. However, we do not 
consider random organizations a reliable source of expertise due to their funding to pursue their purposes. An objective and impartial view on the gender challenges in Bulgaria requires independent research, which could provide a rational assessment of the U.S. impact on gender politics. Finally, it is methodologically relevant to assume that LGBT+ Bulgarians, who have been victims of domestic violence or rural accidents, will have little if any motivation to assist us in this study. However, the articles still prove consistent violations that, we assume, should be subject to a criminal investigation.

\subsection{LGBT+ rights: the Bulgarian misperceptions.}

What do we mean by LGBT+ rights? The concept of normality is crucial for the understanding of Bulgarian perceptions of gender. Assuming that LGBT+ people are equal to the other Bulgarians is central to the misperceptions of the society. Thus, public opinion envisions gender rights and freedoms as "parading" sexuality (McGarry, 2016, p. 272). Therefore, the cleavage between normality and parading constitutes the first pillar of Bulgarian perceptions on LGBT+ rights.

The second perception concerns the primordial right to live. However, Bulgarian attitudes on the universal freedom of LGBT+ vary from a straight person to a gay/lesbian. The tragic case of the young Bulgarian Mikhail Stoyanov is an empirical example of gender discrimination and deprivation of fundamental rights given to all people by birth (Davis, 2000, p. 7). Mikhail was an ordinary student who went out for a walk but never returned. He was attacked and killed by a gang of teens who claimed to be "clearing" the park of gay people. Mikhail "looked" gay to them, so they assassinated him, even though the student was straight. The attackers were eventually arrested but got relatively short sentences, while the nature of their crime was poorly articulated in the Court (Karsay, 2018).

The third perception refers to a right given to all Bulgarian citizens, but less so to LGBT+ ones. It is the moral right of expression, including showing the affection one feels on an emotional level. To assume that straight Bulgarians enjoy their rights to share emotional affection is to state a fact. However, to argue that LGBT+ Bulgarians are not deprived of those freedoms is deeply misleading. Another case study that we have analyzed involves two young gay underage people who were attacked for going to a restaurant together (Atanasova, 2021). In Plovdiv, the second-largest populated city in Bulgaria, attacks are so common that they have been dubbed "The European capital of homophobia" (Forby and Batsleer, 2020, p. 500). Moreover, for LGBT+ Bulgarians, it is extremely difficult to share a culture that provides them with similar interests and hobbies. In 2021, a children's book about a talking ant adopted by a same-sex couple caused an uproar and even attacks on the publisher (Stefanova, 2021). A movie condemning homophobia was also attacked by people who compared gay people to pedophiles (Atanasova, 2013). The final misperception refers to same-sex marriages, which are not regulated by the Bulgarian legislature. Because they are denied information about their partner in case of a medical emergency, they cannot inherit them after the latter 
passes away. Thus, homophobic relatives would be able to cut them out of any relation to the memory of their significant other. In Bulgaria, the institution of marriage is determined by the Bulgarian Constitution to be between a man and a woman. However, other forms of recognition can be applied. Thus, misperceptions emerge from wrong attitudes, part of which follow the postsocialist nature of the Bulgarian society. To conclude, the article infers two starting points for reconciling the misperceptions: protection of discrimination based on sexual orientation or gender identity and legal recognition for samesex couples. To sum, this paper operationalizes empirical data to calculate the comparative trends of gender discrimination in Bulgaria and the European Union, which incorporates four variables: harassment and hate speech, intolerance and prejudice, open discrimination, and homophobia in Bulgarian schools. The second branch of data offers a plausible empirical basis for the calculation of another index that we summarize as index of LGBT+ support in Bulgarian schools. For calculating both indexes, we collected empirical data from the European Agency of Fundamental Rights. Then, we infer our quantitative variables in the figures below. Our calculations specify the existence of another conditional variable, which affects the results: BREXIT. In the following statistics, the presented quantitative data includes the United Kingdom, then part of the European Union.

Figure 1. Comparative trends of gender discrimination in Bulgaria/EU.

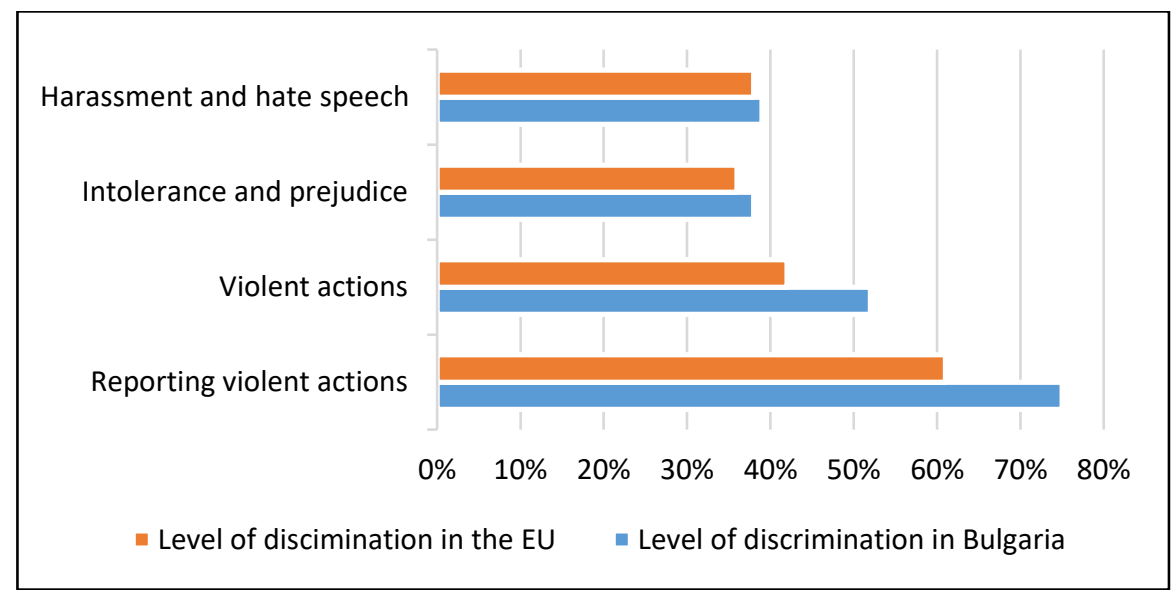

Source: European Union Agency of Fundamental Rights. 
Figure 2. Index of LGBT+ support in Bulgarian and EU schools.

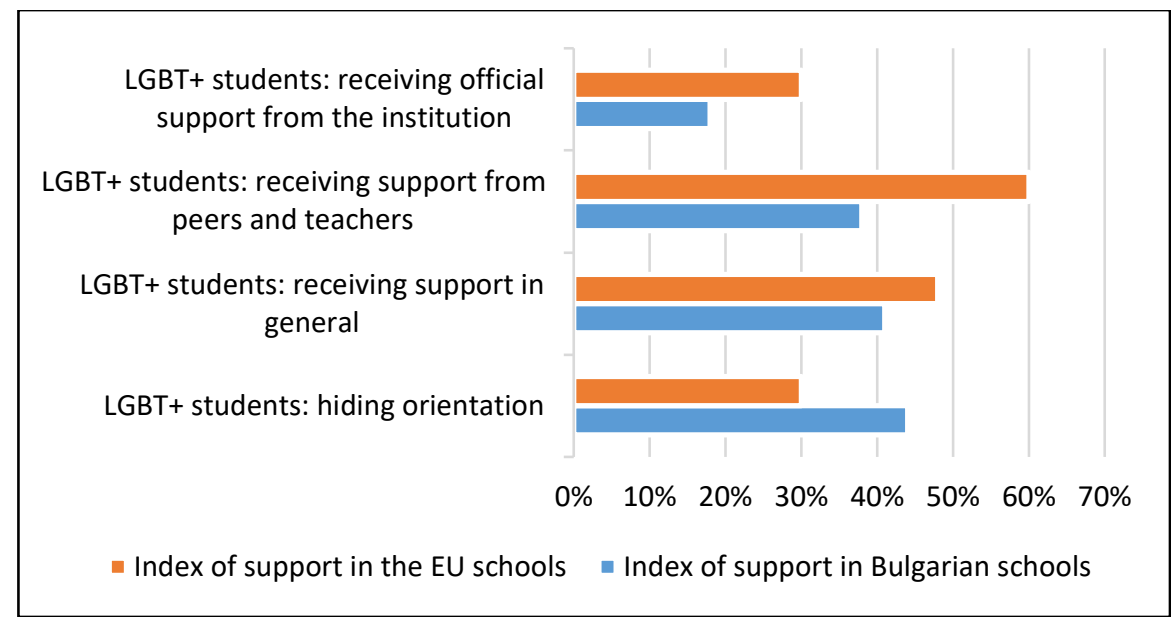

Source: European Union Agency of Fundamental Rights.

The data, introduced in the previous paragraphs, overlaps partially with our predictions. First, comparative trends of gender discrimination in Bulgaria and the European Union do not coincide. Most scholars, who stress variables such as harassment, hate speech, intolerance, and prejudice, typically analyze gender discrimination in Eastern Europe without calculating the possibility of violent actions against the LGBT+ community. Therefore, much of the explanations of discriminatory practices are limited to verbal or symbolic xenophobia assessment. The other side of the coin is that genuine acts of violence in Bulgaria largely exceed the violent actions in the European Union. Therefore, a more profound explanation of gender discrimination in Bulgaria presumes examining variables such as the number of violent acts and reported accidents. The striking differences in analyzed data reaffirm our thesis that the public debate in Bulgaria reflects the neo-conservative attitudes of Russia and Moscow's policy of violent discrimination. Thus, our first conclusion is that the level of gender discrimination in Bulgaria is above the European average due to the more violent implications of xenophobia and political extremism.

We also offer a comparative operationalization of another essential variable that we define as index of support for LGBT+ students. The calculations presented in the previous paragraphs introduce the extent to which LGBT+ representatives of the younger generation enjoy support for their sexual orientation. It is important to highlight that one should not confuse the official support of the educational institution with the assumption that the Bulgarian state would support LGBT+ students officially. Some schools examined in the European Union Agency of Fundamental Rights survey are private institutions. The Bulgarian government does not provide financial grants for private higher education. Our second conclusion is that LGBT+ students in Bulgaria are more likely to hide their orientation than their European fellows. The levels of support for the young LGBT+ minorities, on the other side, are higher in 
Europe. Although EU Member States, Bulgaria does not tolerate gender behavior, which is premised on the assumption that students will enjoy the support of their friends or teachers. Moreover, it is evident that what is common for educational institutions in Europe might be a pathology for Bulgarian schools. It is then essential to stress the need for state funding to prevent gender discrimination before it emerges into regular school violence.

Finally, one should distinguish between the evident gender discrimination in Bulgaria and those that have never been discussed in public opinion. Theoretically, most Bulgarians exercise the former. In practice, however, extremist groups in Bulgarian society implement the latter. Similarly, gender discrimination can provoke criticism from conservative groups in Europe: the national identity of Bulgarians does not presume to recognize LGBT+ rights. However, one should again distinguish between conservatives, who seek to explain their assumptions, and populists, who utilize conservative rhetoric to gain influence. The former aims to establish a dialogue with the LGBT+ communities and favor a more balanced approach to gender politics. The latter typically resort to violent acts, which undermines the Bulgarian position in Europe.

\subsection{Gender aspects of U.S. Foreign Policy in Bulgaria.}

The second variable we need to assess is the American influence on the issues discussed above. This article argues that U.S. soft power in Bulgaria has three essential aspects, corresponding to what we define as "gender policy." Our claim relies on the assumption that American soft power after September 11 has three basic pillars: liberalism, multilateralism, and neighborhood policy (Ivanov, 2020, p. 49). Thus, by gender policy, we mean the promotion of gender ideology through liberal values. Our definition follows the original explanation of Joseph Nye that soft power occurs when one country gets other countries to want what it wants (Nye, 1990, p. 166).

The first aspect concerns what we call official influence. It represents the official position of the U.S. government, released through the U.S. Embassy in Sofia. The support of the Embassy is praiseworthy and particularly positive. Like the United States, Europe is highly engaged in defending and supporting LGBT+ rights in Bulgaria through several NGOs and intergovernmental agencies.

The second aspect is the American popular culture, or soft power: music, movies, TV broadcasts, and sports. Stars like Madonna, Katy Perry, and Lady Gaga are well known for their support of LGBT+ rights and thus have become heroes for the community and favorite singers of LGBT+ youth. While not many, there are a few Bulgarian pop stars who followed the example of their American counterparts, like the popular folk singer Galena.

The final aspect involves religion. Evangelical groups are predominant, but there are some religious sects that also share the traditional American values. The American Protestants have been establishing a solid branch of lobbyist organizations since the rise of Bulgarian democracy. However, even in support 
of Western culture, religious groups are highly hostile towards LGBT+ people in Bulgaria. "Agenda Europe" is the leading organization closely tied to American right-wing conservatives (Darakchi, 2019, p. 1210).

\subsection{Intervening the variables: LGBT-friendly policy in a homophobic state.}

It has to be said that the essential American influence on the debate about Bulgarian LGBT+ rights originates not from official sources but from American popular culture. The American broadcasts, TV shows, movies, and music are popular among young people in Bulgaria, particularly among netizens and users of social media. TV series like "Glee" or "Shadowhunters" have normalized, among many underage people, the concept of having a member of the LGBT+ community for a friend or even a relative. Campaigns from websites like Facebook, with its "frames" for support of equality and acceptance, allow gay young people to express their support for one another. Unfortunately, while the U.S. moderators in Facebook seem to be relatively strict about removing homophobic content from social media, their Bulgarian counterparts seem to have a more relaxed approach. Because of that, gay people can often become victims of hateful content on the network. Another peculiar problem appears to be weaponizing good intent for ill purposes, like taking words out of context to ban government officials. This happens due to mass reports by organized users, commonly known by the slang "trolls."

The official support of the United States also gives a semblance of legitimacy for LGBT+ people, despite the lack of laws focused on protecting them from hate crimes. They can quote progress in America as an example for improving the situation in Bulgaria, more particularly when the country is ruled by a Democratic administration such as the one of Barack Obama or Joe Biden, though it should be stressed that even during President Trump's reign, America never wavered in its support for equality in Bulgaria.

Unlike traditional homophobes, the pro-family conservative groups have managed to use their experience from the culture wars in the United States to make arguments against the LGBT+ community, at least some of which are in bad faith, like comparing gay people to pedophiles, for example. These groups are also allied with the Russophile circles in the country and the far-right and are particularly well represented in the arch-conservative party VMRO due to Alexander Urumov, an influential opinion maker and writer. He claims to fight the so-called gender propaganda (Leustean, 2021, p. 85).

\section{Conclusion.}

In the final section of our article, we will summarize our conclusions about the research question we posed: can we say that official American influence favors the rights of LGBT+ people in Bulgaria? The answer to this article is yes. Although the American influence strengthens due to the close political ties between Bulgaria and the United States, some American conservatives challenge that progress, obscuring the positive outcomes from traditional U.S. 
support. History shows a better parallel for the detrimental effects of conservative attitudes.

Bulgaria has never been a welcoming place for sexual minorities. There is little, if any, data from medieval times. After the Ottoman Empire conquered the Balkans, Bulgarian people lived under Ottoman rule, guided by the conservative Islamic worldview, which is not benevolent for same-sex attraction or changing your gender, regardless of anecdotal rumors about the preferences of even the sultans themselves. After the Liberation of Bulgaria in 1878 , the majority of the population remained in small towns or villages, keeping the traditional view of sexuality. For LGBT+ people, things even worsened in the years before World War II because of the rise of nazism, fascism, and Stalinism. In the aftermath of the War, and due to the discriminatory policy pursued by the Bulgarian Communists, homosexuality was criminalized, and gay people were mostly labeled with insulting and dehumanizing narratives. In the 1950s, it was decided that homosexual acts were punished with up to five years in prison. Later, in the late 1960s and up to the 1980s, homosexuality was considered a mental illness rather than a crime. As part of the socialist Soviet block, Bulgaria was following the USSR's example and left little place for the uprisings that shattered America.

Attitudes did not immediately change after the fall of the Soviet block and the rule of the Bulgarian Communist Party. Still, homosexuality is no longer treated as a crime or a mental illness, at least not in the eyes of the law. In the 1990s, there was a famous music club in Sofia, "Spartacus," which was (in)famous for accepting gay people. Actor Marius Kurkinski, openly gay and supportive of LGBT+ rights, became popular with some provocative songs. However, the first Sofia Pride march came in 2008, after Bulgarian joined the European Union. Initially, the Pride was attacked by far-right activists, but thankfully no people were hurt. With time, popularity and support for the Pride steadily grew, and in 2021 it attracted more than 10,000 people McGarry, 2016, p. 280). It has to be said that the opinions about LGBT+ rights in the USA itself changed dramatically when President Obama declared support for same-sex marriage, which showed a massive shift in attitudes of Americans (Steinmetz, 2015). The rise of Sofia Pride and the visibility of LGBT+ people coincided with that.

However, in recent years opposition to LGBT+ rights has also increased. In reference to the Istanbul Convention, we are reminded that evangelical leaders, including Alexander Urumov, loyal support of President Trump, openly opposed its ratification (Darakchi, 2019, p. 1212). During the arguments against the Convention, the role of US pro-family groups and evangelicals have been noted, particularly of the "World Congress of Families," an arch-conservative protestant group (Darakchi, 2019, p. 1213). We know that gay rights have been a hot button of the culture wars. It is believed that in 2004 the support of the "value voters," conservative-leaning religious leaders, was instrumental in the reelection of Republican George W Bush. Authors have speculated that cultural backlash is also the main factor in the election of Donald J. Trump in 2016. Conversely, LGBT+ voters might have proved to be crucial for the reelection of Obama for his second term, showing that they have significant political 
power. (Johnson, 2012) Similarly, it is believed that in 2020, LGBT+ voters were one of the keys to the monumental victory of Joe Biden, as they overwhelmingly supported him in swing states.

Thus, we can conclude that the U.S. influence on Bulgaria creates a domino effect. The effect amplifies when the issue of discrimination is raised in public debate, making it an essential facet in the rhetoric of most politicians, be they nationalists or liberals. Civil movements in both countries are fighting for rights, making them part of the political process. Politicians, however, face reelections, which makes them more inclined to express ambiguous statements. One, however, should not forget the essential contributions of American and Bulgarian cultures to gender attitudes in both countries. Paradoxically, one of the things they differ in is LGBT+ support. While the official American position and its popular culture have been of tremendous help to promote LGBT+ rights, conservative forces opposing them in the United States have exported their resistance to the Balkan country. Then, facing a less accepting populace, they have been quite innovative in preventing the progress in Bulgaria, although probably taking a secondary position to Russian antigay propaganda. The American influence generally benefits the rights of LGBT+ Bulgarians. The official position of the Embassy and the U.S. popular culture improve the political climate for LGBT+ people, counter the influence of proRussian homophobic groups, and help with encouraging the protection of LGBT+'s people freedom of speech and peaceful protest. However, there is opposition to LGBT+ rights in the U.S. itself, which exports itself to other countries like Bulgaria, creating polarization, mirroring America's culture wars. Therefore, Bulgarian society is not yet ready to integrate LGBT+ people into its political and ideological perceptions. The United States, quite the opposite, remains a symbol of the hope that inspires those who seek to achieve it. 


\section{References}

2020 Country Report on Human Right Practices: Bulgaria. (2020). Retrieved on October 30, 2021, from https://www.state.gov/reports/2020country-reports-on-human-rights-practices/bulgaria/

Atanasova, M. (2021). How do the state and society talk about violence? The multiple actors in the Bulgarian case of the Istanbul. (2021). Retrieved on December 15, 2021, from https://www.etd.ceu.edu/2021/atanasova_maria.pdf

Bankov, K. (2020). Cyberbullying and hate speech in the debate around the ratification of the Istanbul convention in Bulgaria: a semiotic analysis of the communication dynamics. Social Semiotics, 30(3), 344-364. https://doi.org/10.1080/10350330.2020.1731175

Belkin, A. (2003). Don't Ask, Don't Tell: Is the Gay Ban Based on Military Necessity?. The US Army War College Quarterly: Parameters, 33(2), 4. Retrieved on December 15, 2021, from https://press.armywarcollege.edu/cgi/viewcontent.cgi?article=2144\&c ontext=parameters

Burke, C., \& Molitorisová, A. (2019). Reservations/Declarations under the Council of Europe Convention on Preventing and Combating Violence against Women and Domestic Violence (Istanbul Convention) and Convention on the Elimination of All Forms of Discrimination against Women (cedaw) in Light of Sex/Gender Constitutional Debates. International Human Rights Law Review, 8(2), 188-214. Retrieved on December 15, 2021, from https://brill.com/view/journals/hrlr/8/2/article-p188_188.xml

Burks, D. J. (2011). Lesbian, gay, and bisexual victimization in the military: An unintended consequence of "Don't Ask, Don't Tell"?. American Psychologist, 66(7), 604, http://doi.org/10.1037/a0024609

Constitution of Bulgaria. (2021). Retrieved on October 31, 2021, from https://www.parliament.bg/en/const

Council of Europe. (2018). Council of Europe Convention on preventing and combating violence against women and domestic violence. Text of Convention. Council of Europe, Brussels. Retrieved on December 15, 2021, from https://rm.coe.int/168008482e

Darakchi, S. (2019). The Western Feminists Want to Make Us Gay": Nationalism, Heteronormativity, and Violence Against Women in Bulgaria in Times of "Anti-gender Campaigns. Sexuality \& Culture, 23(4), 1208-1229. https://doi.org/10.1007/s12119-01909611-9

Darakchi, S. (2019). The Western Feminists Want to Make Us Gay": Nationalism, Heteronormativity, and Violence Against Women in Bulgaria in Times of "Anti-gender Campaigns. Sexuality \& Culture, 23(4), 1208-1229. https://doi.org/10.1007/s12119-01909611-9 
Darakchi, S. (2019). The Western Feminists Want to Make Us Gay": Nationalism, Heteronormativity, and Violence Against Women in Bulgaria in Times of "Anti-gender Campaigns. Sexuality \& Culture, 23(4), 1208-1229. https://doi.org/10.1007/s12119-01909611-9

Darakchi, S. (2019). The Western Feminists Want to Make Us Gay": Nationalism, Heteronormativity, and Violence Against Women in Bulgaria in Times of "Anti-gender Campaigns. Sexuality \& Culture, 23(4), 1208-1229. https://doi.org/10.1007/s12119-01909611-9

Darakchi, S. (2019). The Western Feminists Want to Make Us Gay": Nationalism, Heteronormativity, and Violence Against Women in Bulgaria in Times of "Anti-gender Campaigns. Sexuality \& Culture, 23(4), 1208-1229. https://doi.org/10.1007/s12119-01909611-9

Darakchi, S. (2021). Bulgarian LGBTQI movement: Generations, identifications, and tendencies. Sexualities, 13634607211000201. https://doi.org/10.1177\%2F13634607211000201

Davis, M. (2002). The United Nations Draft Declaration 2002. Indigenous Law Bulletin, 5(16), 6-9. Retrieved on December 15, 2021, http://www5.austlii.edu.au/au/journals/IndigLawB/2002/22.html

EU LGBTI survey II A long way to go for LGBTI equality. Country data: Bulgaria. (2019). Retrieved from the Website of the European Agency for Fundamental Rights. Retrieved on October 30, 2021, from https://fra.europa.eu/sites/default/files/fra_uploads/lgbti-surveycountry-data_bulgaria.pdf

Forkby, T., \& Batsleer, J. (2020). In search of the beloved community: dancing to a different tune of youth participation. Ethnography and Education, 15(4), 493-508. https://doi.org/10.1080/17457823.2020.1716261

Godzisz, P., \& Viggiani, G. (2019). Awareness of Anti-LGBT Hate Crime in Europe. Lambda Warsaw. Retrieved on December 15, 2021, from http://www.open-

access.bcu.ac.uk/8845/1/2019\%20Awareness\%20of\%20Anti-

LGBT\%20Hate\%20Crime\%20in\%20the\%20European\%20Union.pdf

Hermann, D. H. (2015). Extending the fundamental right of marriage to samesex couples: The United States Supreme Court decision in Obergefell v. Hodges. Ind. L. Rev., 49, 367. Retrieved on December 15, 2021, from https://mckinneylaw.iu.edu/ilr/pdf/vol49p367.pdf

Hollywood, C. A. (2013). Reagan's Silent Majority: Conservative Welfare Politics after Nixon. Scott Spitzer. Retrieved on December 15, 2021, from http://www.wpsanet.org/papers/docs/Spitzer\%20\%20WPSA\%202013.pdf

Howard, J. R. (1969). The flowering of the hippie movement. The Annals of the American Academy of Political and Social Science, 382(1), 43-55. https://doi.org/10.1177\%2F000271626938200106 
Ilcheva, M. (2020). Bulgaria and the Istanbul Convention-Law, Politics and Propaganda vs. the Rights of Victims of Gender-Based Violence. Open J. Legal Stud., 3, 49. https://doi.org/10.32591/coas.ojls.0301.04049i

Ivanov, I. (2020). Reshaping US Smart Power. Journal of Strategic Security, 13(3), 46-74. https://www.jstor.org/stable/10.2307/26936545

J.K. Rowling Writes about Her Reasons for Speaking out on Sex and Gender Issues. (2020). Retrieved October 30, 2021, from https://www.jkrowling.com/opinions/j-k-rowling-writes-about-herreasons-for-speaking-out-on-sex-and-gender-issues/

Johnson, Chris (2012, November 7), Trans voters excluded in election exit poll, Washington Blade. Retrieved on October 30, 2021, from https://www.washingtonblade.com/2012/11/01/trans-voters-excludedin-election-exit-poll/

Karsay, D. (2018). Protecting LGBTQI rights in Europe. Submission to the second. Retrieved on December 15, 2021, from https:/www.sogica.org/wp-content/uploads/2018/10/coe-submission18-tgeu-ie-oii_0.pdf

Leustean, L. N. (2021). Orthodox Conservatism and the Refugee Crisis in Bulgaria and Moldova. Communist and Post-Communist Studies, 54(1-2), 83-101. https://doi.org/10.1525/j.postcomstud.2021.54.1-2.83

McGarry, A. (2016). Pride parades and prejudice: Visibility of Roma and LGBTI communities in post-socialist Europe. Communist and postcommunist studies, 49(3),

269-277. http://dx.doi.org/10.1016/j.postcomstud.2016.06.002

McGarry, A. (2016). Pride parades and prejudice: Visibility of Roma and LGBTI communities in post-socialist Europe. Communist and postcommunist studies, 49(3),

269-277. http://dx.doi.org/10.1016/j.postcomstud.2016.06.002

McVeigh, R., \& Maria-Elena, D. D. (2009). Voting to ban same-sex marriage: Interests, values, and communities. American Sociological Review, 74(6), 891-915. https://doi.org/10.1177\%2F000312240907400603

Nye, J. S. (1990). Soft power. Foreign policy, (80), 153-171. https://www.jstor.org/stable/1148580

See Obama's 20-Year Evolution on LGBT Rights. (2015). Retrieved on October 31, 2021, from https://time.com/3816952/obama-gay-lesbiantransgender-lgbt-rights/

Statement of Support for Sofia Pride 2017. (2017). Retrieved on October 30, 2021, from https://bg.usembassy.gov/statement-support-sofia-pride$2017 /$

Stoencheva, J. (2021). Turkish Yoke, Red Vampires, and Euro-Genderists: Strategies of de/legitimization in the debate around the Istanbul Convention in Bulgaria. Retrieved on December 15, 2021, from https://www.diva-portal.org/smash/get/diva2:1566953/FULLTEXT02 
Strand, C., \& Svensson, J. (2021). Disinformation campaigns about LGBTI+ people in the EU and foreign influence. Retrieved on December 15, 2021, from https://www.europarl.europa.eu/RegData/etudes/BRIE/2021/653644/ EXPO_BRI(2021)653644_EN.pdf

Thomson, I. T. (2010). Culture wars and enduring American dilemmas. University of Michigan Press. 